\title{
PENGETAHUAN DAN DUKUNGAN SOSIAL MENINGKATKAN SELF-CARE BEHAVIOR PADA ANAK SEKOLAH DENGAN THALASEMIA MAYOR
}

\author{
Indanah $^{1,2 *}$, Krisna Yetti ${ }^{3}$, Luknis Sabri ${ }^{4}$ \\ 1. STIKES Muhammadiyah Kudus, Jawa Tengah 59316, Indonesia \\ 2. Program Studi Magister Fakultas Ilmu Keperawatan Universitas Indonesia, Depok 16424, Indonesia \\ 3. Fakultas Ilmu Keperawatan Universitas Indonesia, Depok 16424, Indonesia \\ 4. Fakultas Kesehatan Masyarakat Universitas Indonesia, Depok 16424, Indonesia \\ *Email:nok_iin75@yahoo.com
}

\begin{abstract}
Abstrak
Penyakit thalasemia merupakan kelainan genetik tersering di dunia. Di Indonesia, penyakit ini telah menjadi penyakit yang membutuhkan penanganan yang serius. Penelitian ini bertujuan untuk mengungkapkan faktor-faktor yang berhubungan dengan Self-care Behavior pada anak sekolah penderita thalasemia mayor. Penelitian kuantitatif dengan desain cross sectional ini dilakukan terhadap 131 pasien usia sekolah penderita thalasemia mayor yang berkunjung ke rumah sakit X dari tanggal $1 \mathrm{Mei}$ hingga 10 Juni 2010. Hasil penelitian, dengan menggunakan analisis multivariat menunjukkan ada hubungan antara pengetahuan dan dukungan sosial dengan selfcare behavior, dengan pengetahuan yang paling dominan mempengaruhi ( $\mathrm{p}=0,000 ; \alpha=0,05$; $\mathrm{OR}=31,6)$. Penelitian ini merekomendasikan untuk meningkatkan pendidikan kesehatan dan dukungan sosial untuk meningkatkan perilaku perawatan diri penderita thalasemia.
\end{abstract}

Kata kunci: anak usia sekolah, self-care behavior, thalasemia mayor

\section{Abstract}

Thalassemia disease is a common genetic disorder in the world. In Indonesia, it has become a disease that requires serious treatment. This study aims to discover factors related to Self-care Behavior in school children with thalassemia major. This quantitative research with cross sectional design was conducted on 131 patients school-age with thalassemia major who visited hospital X from May 1 to June 10, 2010. The results of study, using multivariate analysis showed there is no relation between knowledge and social support with self-care behavior, with the knowledge of the most dominant influence ( $p=0.000$; $\alpha=0.05 ; O R=31.6)$. The study recommends to improving health education and social support to improve self-care behaviors of patients with thalassemia.

Keywords: school age children, self-care behavior, major thalassemia

\section{Pendahuluan}

Penyakit thalasemia merupakan kelainan genetik tersering di dunia. Kelainan ini terutama ditemukan di kawasan Mediterania, Afrika dan Asia Tenggara dengan frekwensi sebagai pembawa gen sekitar 5 sampai 30\% (Martin, Foote, \& Carson, 2004). Prevalensi carrier thalasemia di Indonesia mencapai sekitar 3 - 8\%, hingga Maret 2009 kasus thalasemia di Indonesia mengalami peningkatan sebesar 8,3\% dari 3653 kasus yang tercatat pada tahun 2006 (Wahyuni, 2008).

Data Perhimpunan Yayasan Thalasemia Indonesia tercatat hingga Juni 2008, RSCM telah merawat
1.433 pasien. Sejak 2006 sampai 2008 rata-rata pasien baru thalasemia meningkat sekitar $8 \%$, dan diperkirakan banyak kasus yang tidak terdeteksi, sehingga penyakit ini telah menjadi penyakit yang membutuhkan penanganan yang serius (Yayasan Thalassemia Indonesia, 2009).

Pasien thalasemia mengalami perubahan fisik dan psikososial. Perubahan fisik antara lain mengalami anemia yang kronik yang dapat menyebabkan pasien mengalami hypoxia, sakit kepala, irritable, anorexia, nyeri dada dan tulang, serta intoleransi aktivitas. Pasien thalasemia juga mengalami gangguan pertumbuhan dan perkembangan sistem reproduksi (Hockenberry \& Wilson, 2009). 
Perubahan fisik tersebut juga berdampak terhadap psikososial pada pasien. Pasien thalasemia merasa; berbeda dengan kelompoknya, terbatas aktivitas, mengalami isolasi sosial, rendah diri, serta cemas akan kondisi sakit dan efek lanjut yang mungkin timbul (Hockenberry \& Wilson, 2009).

Untuk meminimalkan dampak, baik fisik maupun psikologis, dibutuhkan penatalaksanaan yang tepat untuk pasien thalasemia. Keberhasilan penanganan thalasemia terletak pada keberhasilan mengatasi dampak anemia. Tanpa penatalaksanaan yang baik, penderita thalasemia sulit mencapai usia di atas 20 tahun, 71\% pasien thalasemia meninggal karena gagal jantung kongesti sebagai dampak kerusakan organ karena akumulasi zat besi (Wahyuni, 2009).

Dampak anemia yang terjadi berhubungan dengan perilaku dalam perawatan diri (Self care behavior). banyak studi yang meneliti tentang selfcare behaviour, namun penelitian yang terkait dengan selfcare behaviour pada anak usia sekolah yang menderita thalasemia belum pernah dilakukan. Penelitian ini bertujuan agar diketahuinya faktorfaktor yang berhubungan dengan selfcare behaviour pada anak usia sekolah penderita thalasemia mayor.

\section{Metode}

Penelitian ini merupakan penelitian kuantitatif dengan menggunakan analitik deskriptif dengan desain penelitian cross sectional. Teknik pengambilan sampel pada penelitian ini menggunakan tekhnik non probability sampling dengan pendekatan purposive sampling. Penelitian dilakukan selama 2 minggu, yaitu 31 Mei hingga 10 Juni 2010.

Populasi dalam penelitian ini adalah semua pasien thalasemia mayor usia sekolah yang dirawat di sebuah rumah sakit di Jakarta. Sampel penelitian adalah semua pasien thalasemia mayor usia sekolah yang di rawat sejumlah 131 pasien. Kriteria inklusi adalah anak usia 6 - 12 tahun, lama sakit minimal 1 (satu) tahun, tidak mengalami komplikasi penyakit lain, mampu berkomunikasi secara verbal dan non verbal, Ibu/ keluarga bersedia anak menjadi responden penelitian, mampu membaca, menulis, dan berkomunikasi secara verbal dan non verbal. Kriteria eksklusi pada penelitian ini adalah kondisi anak sangat lemah dan mengalami gangguan kesadaran, Ibu/ keluarga tidak kooperatif, Ibu/ keluarga menolak apabila anak menjadi responden penelitian.

Penelitian ini menggunakan kuisioner yang berisi daftar pertanyaan mengenai data demografi, pengetahuan mengenai thalasemia, status kesehatan, dukungan keluarga, dan selfcare behaviour penderita thalasemia yang sudah dilakukan uji validitas dan reliabilitas dengan menggunakan korelasi Pearson product moment.

Data pada penelitian ini dianalisis dengan menggunakan analisis univariat, bivariat, dan multivariat. Analisis univariat dilakukan pada variabel usia, jenis kelamin, status kesehatan, pengetahuan, dukungan sosial, dan selfcare behavior. Analisis bivariat yang digunakan adalah analisis $t$ test independen dan chi squre. Analisis multivariate digunakan untuk mengetahui faktor yang dominan berpengaruh dengan menggunakan regresi logistik.

\section{Hasil}

Penelitian ini membuktikan dan menjawab pertanyaan penelitian yang diajukan bahwa apakah ada hubungan antara usia, jenis kelamin, lama sakit, status kesehatan, dukungan sosial dengan selfcare behavior pada anak usia sekolah penderita thalasemia.

Berdasarkan hasil penelitian ini didapatkan hasil bahwa selfcare behaviour responden penderita thalasemia sebagian besar dalam kategori yang baik yaitu sebanyak 116 orang (89\%) (lihat dalam Diagram 1). 
Diagram 1. Gambaran Selfcare Behavior pada Anak penderita Thalasemia

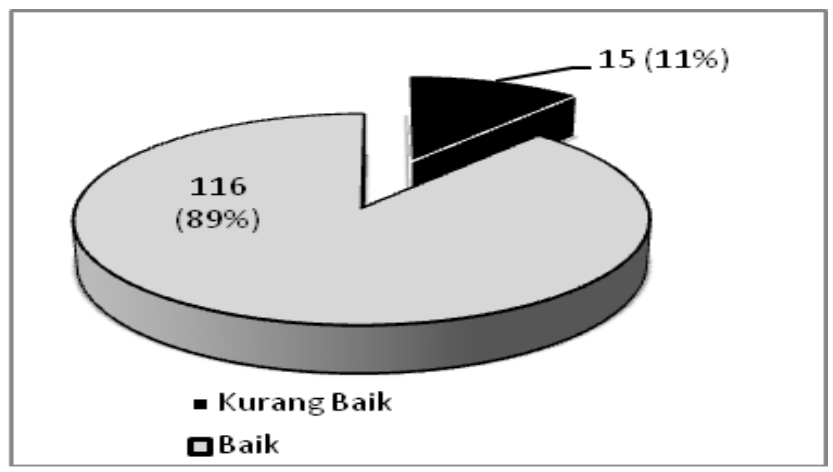

Hasil penelitian ini menunjukkan bahwa selfcare behavior pada anak sekolah penderita thalasemia yang baik ditunjukkan paling besar pada aspek universal selfcare yaitu sebanyak 117 (89\%) dan yang masih kurang pada aspek developmental selfcare yaitu sebanyak $41(31 \%)$ responden.

Pada analisis bivariat menggunakan t-test independence didapatkan bahwa ada perbedaan yang signifikan antara rata rata usia dan lama sakit dengan selfcare behavior thalasemia yang baik dan yang kurang ( $\mathrm{p}=0,000 ; 0,006 ; \alpha=0,05)$ (Lihat pada Tabel 1).

Hubungan antara jenis kelamin, status kesehatan, pengetahuan, dan dukungan sosial dengan selfcare behavior tampak pada tabel 2. Tabel 2 menggambarkan bahwa ada hubungan yang signifikan antara pengetahuan, dukungan sosial dengan selfcare behavior $(p=0,000 ; \alpha=0,05)$, dan tidak ada hubungan yang signifikan antara jenis kelamin, status kesehatan dengan selfcare behavior.

Hasil analisis multivariat pada penelitian ini menunjukkan bahwa variabel yang berhubungan dengan selfcare behavior pada anak usia sekolah penderita thalasemia adalah pengetahuan $(\mathrm{OR}=$ $31,664)$ dan dukungan sosial $(\mathrm{OR}=15,267)$, sedangkan variabel usia sebagai perancu (lihat pada tabel 3). Variabel yang paling bermakna di lihat dari OR yang paling besar, sehingga pada penelitian ini variabel yang paling besar memberikan pengaruh adalah variabel pengetahuan.
Hasil analisis didapatkan OR dari variabel pengetahuan adalah 31,6 artinya anak yang mempunyai pengetahuan selfcare behavior thalasemia baik berpeluang 31,6 kali menunjukkan selfcare behavior yang baik setelah dikontrol dukungan sosial dan usia.

\section{Pembahasan}

\section{Pengetahuan}

Perilaku yang didasari oleh pengetahuan akan lebih langgeng daripada perilaku yang tidak didasari oleh pengetahuan (Notoatmodjo, 2003). Penelitian tentang hubungan pengetahuan mengenai thalasemia dengan kepatuhan menjalani program terapi pernah dilakukan oleh Lee, Lin, dan Tsai (2008) dengan hasil bahwa adanya hubungan yang signifikan diantara keduanya.

Hasil penelitian yang sama dikemukakan oleh Yang, et al. (2001) yang mengungkapkan bahwa pengetahuan merupakan salah satu faktor yang mendukung perawatan diri sehari hari (selfcare behaviour), karena dengan pengetahuan yang cukup, seseorang akan memahami kondisi fisiknya dan diharapkan mampu menunjukkan selfcare behavior yang baik untuk mendukung upaya dalam mempertahankan kesehatan.

Newland (2008) mengungkapkan juga dalam penelitiannya bahwa pengetahuan berhubungan dengan kemampuan mengatur perawatan dirinya pada remaja dengan sickle cell disease. 
Diagram 2. Permodelan Faktor yang Berhubungan dengan Selfcare Behavior pada Anak dengan Thalasemia

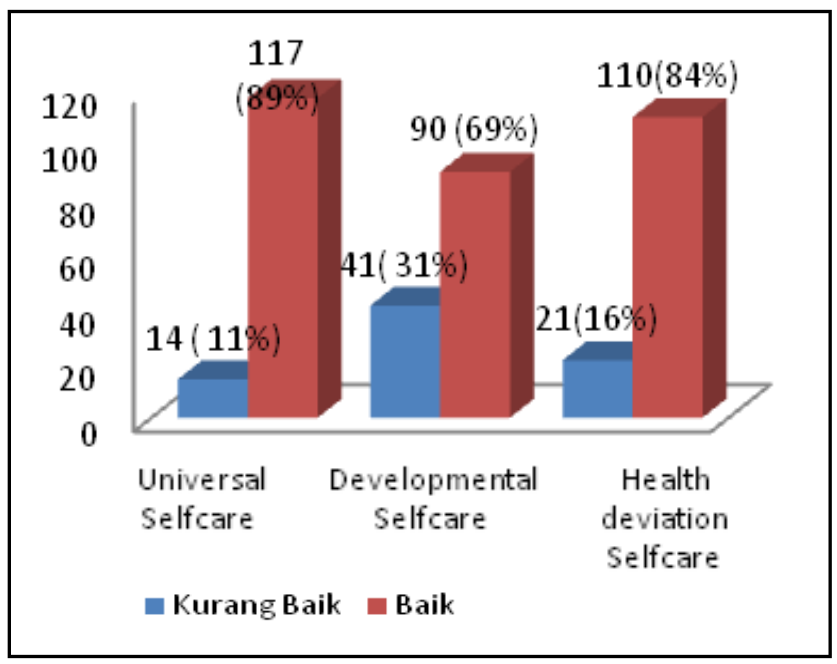

Pengetahuan dapat ditingkatkan dengan memberikan pendidikan kesehatan yang sesuai dengan kebutuhan pasien.

Berdasar hasil analisis terkait pengetahuan pasien mengenai faktor genetik thalasemia, penyebab jaundice, penatalaksanaan dengan mempertahankan kadar $\mathrm{Hb}$ pada level $10 \mathrm{mmHg}$ serta jenis permainan yang seharusnya diperhatikan untuk pasien thalasemia, tidak begitu dipahami oleh responden. Dengan demikian hasil tersebut dapat dijadikan bahan bagi perawat yang untuk memberikan pendidikan kesehatan.

Perawat harus memberikan informasi bahwa thalasemia merupakan penyakit genetik yang diturunkan dari kedua orangtua. Anak juga perlu diberitahu cara memilih jenis permainan yang bisa meminimalkan penggunaan energi. Anak yang menderita thalasemia harus diupayakan untuk melakukan aktivitas yang tidak menguras tenaga, bermain, dan beristirahat dengan tenang serta melakukan aktivitas fisik yang sesuai dengan kemampuan (Wong, 2004).

\section{Dukungan Sosial}

Sumber dukungan sosial yang berperan dalam selfcare behaviour anak usia sekolah adalah dukungan psikososial dari keluarga dan teman sebayanya (Orem, 2001). Keluarga berperan dengan membantu mengontrol perilaku anak menghadapi perubahan fisik dan psikologis. Penelitian Newland (2008), yang mengungkapkan bahwa hubungan orang tua dan anak secara langsung berpengaruh dengan kondisi sakit anak dan kemampuan mengatur perilaku terhadap perubahan yang terjadi selama sakit. Dalam memberikan pelayananan keperawatan pada anak, perawat perlu melibatkan peran serta keluarga atau lebih dikenal dengan konsep FamilyCentered Care karena keterlibatan keluarga merupakan unsur penting dalam asuhan keperawatan anak.

Dukungan orangtua yang belum dirasakan pasien adalah tentang peran-serta orangtua untuk memberikan diet rendah zat besi untuk anaknya. Menurut anak, orangtua tidak pernah menyiapkan makanan yang rendah zat besi sesuai dengan diet yang seharusnya pada thalasemia.

Hasil penelitian ini juga mengindikasikan bahwa perlunya upaya dalam peningkatan dukungan (pembelajaran) terhadap orangtua dengan memberikan pendidikan kesehatan kepada mereka (orangtua) mengenai pengaturan diet rendah zat besi untuk pasien thalasemia. Hal ini disebabkan karena penderita thalasemia memiliki potensi mengalami terjadinya penumpukan zat besi yang berbahaya bagi kesehatan tubuhnya. 
Tabel 1. Hubungan Usia dan Lama Sakit dengan Selfcare Behavior pada Anak dengan Thalasemia

\begin{tabular}{llcccc}
\hline Variabel & \multicolumn{1}{c}{$\begin{array}{c}\text { Selfcare Behavior } \\
\text { Talasemia }\end{array}$} & $\begin{array}{c}\text { Mean } \\
\text { (th) }\end{array}$ & SD & p & n \\
\hline \multirow{2}{*}{ Usia } & Kurang & 7,3 & 1,5 & 0,000 & 15 \\
& Baik & 9,6 & 1,8 & & 116 \\
& & & & 0,006 & 15 \\
\multirow{2}{*}{ Lama Sakit } & Kurang & 5,0 & 1,7 & & 116 \\
& Baik & 7,0 & 2,6 & & \\
\end{tabular}

Dengan mengkonsumsi makanan yang mengandung rendah zat besi diharapkan penderita thalasemia dapat mengurangi risiko penumpukan zat besi dalam tubuh sehingga mengurangi komplikasi (Wong, 2004).

Sumber dukungan yang lain bagi anak usia sekolah adalah teman sebayanya. Pada tahap usia sekolah anak lebih banyak menghabiskan waktunya bersama teman-teman sebaya. Anak mempunyai rasa kekawatiran jika tidak dapat terlibat dalam aktivitas bersama teman-teman (Santrock, 2002).

Berdasar hasil analisis yang didapatkan bahwa hanya $78(59 \%)$ responden melaporkan mendapatkan dukungan dari teman sebaya. Dukungan paling banyak ditunjukkan dengan adanya keterlibatan teman dalam aktivitas bermain yang tidak menguras energi anak. Sedangkan, dukungan teman sebaya yang paling rendah dirasakan oleh anak adalah kunjungan teman jika dirawat di rumah sakit.

Anak yang menderita penyakit kronis seperti thalasemia harus menjalani program terapi secara rutin sehingga anak tidak bisa terlibat dalam aktivitas dengan teman sebayanya. Oleh karena itu, upaya untuk mengurangi dampak perpisahan dengan teman sebaya adalah dengan tetap menjaga kontak selama pasien dirawat di rumah sakit.
Dukungan sosial, terutama keluarga dan teman sebaya, merupakan sumber yang sangat penting dalam selfcare behavior (Yang, et al., 2001; Chen \& Wang, 2007). Keluarga berperan serta dalam menolong anak menghadapi berbagai terapi dan prosedur yang dilakukan, serta membantu menghadapi komplikasi yang mungkin terjadi, sedangkan teman sebaya berperan dalam pembentukan identitas sosial anak (Santrock, 2002).

\section{Status Kesehatan}

Pasien thalasemia mengalami berbagai perubahan fisik, gangguan pertumbuhan, dan perkembangan, serta mempunyai risiko mengalami komplikasi karena adanya penumpukan zat besi dalam jaringan (Hockenberry \& Wilson, 2007).

Hasil analisis data yang didapatkan mengenai hubungan antara status kesehatan dengan selfcare behaviour menunjukkan bahwa tidak ada hubungan yang signifikan antara status kesehatan dengan selfcare behavior penderita thalasemia. Hal ini bisa terjadi karena thalasemia merupakan penyakit kronis yang berlangsung bertahun-tahun sehingga anak telah beradaptasi terhadap perubahan fisik yang ada serta sudah terbentuk mekanisme koping untuk mengatasi jika terjadi perubahan fisik. Dengan demikian, hal ini menjadi tidak berpengaruh terhadap selfcare behavior anak. 
Tabel 2. Hubungan antara Jenis Kelamin, Status Kesehatan, Pengetahuan, dukungan Sosial dengan Selfcare Behavior pada Anak dengan Thalasemia

\begin{tabular}{|c|c|c|c|c|c|c|c|c|}
\hline \multirow{3}{*}{ Variabel } & \multicolumn{4}{|c|}{ Selfcare Behavior Thalasemia } & \multicolumn{2}{|c|}{ Total } & \multirow{3}{*}{$\begin{array}{c}\text { OR } \\
(95 \% \mathrm{CI})\end{array}$} & \multirow{3}{*}{$\mathbf{p}$} \\
\hline & \multicolumn{2}{|c|}{ Kurang } & \multicolumn{2}{|c|}{ Baik } & \multirow[b]{2}{*}{$\mathbf{n}$} & \multirow[b]{2}{*}{$\%$} & & \\
\hline & $\mathbf{n}$ & $\%$ & $\mathbf{n}$ & $\%$ & & & & \\
\hline \multicolumn{9}{|l|}{ Jenis Kela min } \\
\hline Laki Laki & 5 & 7,7 & 60 & 92,3 & 65 & 100 & 0,467 & 0,286 \\
\hline Perempuan & 10 & 15,2 & 56 & 84,8 & 66 & 100 & $0,15-1,45$ & \\
\hline \multicolumn{9}{|c|}{ Status Kesehatan } \\
\hline Kurang & 7 & 15,6 & 38 & 84,4 & 45 & 100 & 1,796 & 0,436 \\
\hline Baik & 8 & 9,3 & 78 & 90,6 & 86 & 100 & $0,606-5,32$ & \\
\hline \multicolumn{9}{|l|}{ Pengetah uan } \\
\hline Kurang & 10 & 76,9 & 3 & 23,1 & 13 & 100 & 75,3 & $0,000^{*}$ \\
\hline Baik & 5 & 4,2 & 113 & 95,8 & 118 & 100 & $15,663-362,332$ & \\
\hline \multicolumn{9}{|l|}{ Dukungan Sosial } \\
\hline Kurang & 11 & 44 & 14 & 56 & 25 & 100 & 20,036 & $0,000^{*}$ \\
\hline Baik & 4 & 3,8 & 102 & 96,2 & 106 & 100 & $5,607-71,59$ & \\
\hline
\end{tabular}

Hasil penelitian ini menyanggah penelitian yang dilakukan oleh Wang (2006), yang mengungkapkan bahwa selfcare behavior pada pasien dewasa dengan Rhematoid Artritis berhubungan dengan perubahan fungsi fisik. Akan tetapi, hasil penelitian ini mendukung penelitian yang dilakukan oleh Newland (2008), yang mengungkapkan bahwa tingkat keparahan penyakit tidak mempunyai hubungan langsung terhadap ketergantungan remaja yang menderita sickle sick disease dalam menjalankan aktivitas sehariharinya.

Analisis multivariat mengungkapkan bahwa variabel yang berhubungan bermakna adalah pengetahuan dan dukungan social, sedangkan variabel usia sebagai konfoundingnya. Anak usia sekolah mempunyai karakteristik tersendiri dalam selfcare behavior. Dengan meningkatnya pertumbuhan dan perkembangan anak, kemampuan anak dalam perawatan diri juga semakin meningkat.

Pada usia sekolah, anak sudah mampu memahami kondisi sakit yang diderita dan mampu berpartisipasi dalam pemeliharaan status kesehatannya. Pada tahap usia sekolah anak berkurang ketergantungannya dengan orang lain dan mulai bertanggungjawab untuk terlibat dalam upaya perawatan serta upaya mempertahankan status kesehatanya (Fan, 2008).

Hasil penelitian ini menunjukkan bahwa ada perbedaan yang signifikan antara rata-rata usia anak dengan selfcare behavior thalasemia yang baik dengan yang kurang. Kelompok anak yang menunjukkan selfcare behavior yang kurang adalah terbanyak pada kelompok usia 6 (enam) tahun. Sementara, Selfcare behavior yang baik ditunjukkan pada kelompok anak usia 11 dan 12 tahun. 
Tabel 3. Permodelan Faktor-faktor yang Berhubungan dengan Selfcare Behavior pada Anak sekolah penderita Thalasemia

\begin{tabular}{lccccc}
\hline \multirow{2}{*}{$\begin{array}{l}\text { Variabel } \\
\text { B }\end{array}$} & P wald & Exp(B) & \multicolumn{2}{c}{$\begin{array}{c}\text { 95\% CI } \\
\text { for EXP(B) }\end{array}$} \\
\cline { 4 - 5 } & & & & Lower & Upper \\
Usia & 0,385 & 0,156 & 1,469 & 0,863 & 2,501 \\
Pengetahuan & 3,455 & 0,001 & 31,664 & 4,117 & 243,532 \\
Dukungan sosial & 2,726 & 0,002 & 15,267 & 2,672 & 87,218 \\
Constant & $-5,480$ & 0,014 & 0,004 & & \\
\hline
\end{tabular}

Hasil tersebut menguatkan pernyataan dari Orem (2001), yang mengungkapkan bahwa selfcare behavior akan bertambah efektif seiring dengan bertambahnya usia dan kemampuan. Semakin bertambah usia, semakin berkurang ketergantungan dalam selfcare behavior dan semakin mandiri dalam upaya pemeliharaan kesehatan.

Thalasemia mayor mulai menunjukkan gejala secara klinis pada tahun pertama kehidupan. Anak dengan thalasemia mayor cenderung mengalami keterlambatan pertumbuhan dan perkembangan. Dengan kondisi fisik yang ada, anak cenderung lebih banyak tergantung pada orang lain (orangtua) dalam melakukan aktivitas perawatan diri. Akan tetapi, bertambahnya usia anak akan mengurangi ketergantungan pada orangtua. Untuk membantu meningkatkan selfcare behavior pada anak usia muda maka dukungan dan keterlibatan orangtua penting.

Variabel yang paling besar mempunyai pengaruh terhadap selfcare behavior anak usia sekolah penderita thalasemia adalah variabel pengetahuan. Berdasarkan hasil analisis yang didapatkan bahwa nilai OR dari variabel pengetahuan adalah 31,6 , yang artinya anak yang mempunyai pengetahuan yang baik mengenai selfcare behavior thalasemia berpeluang $31,6 \mathrm{kali}$ menunjukkan bahwa selfcare behavior yang baik juga setelah dikontrol oleh dukungan sosial dan usia.

\section{Kesimpulan}

Selfcare Behavior anak usia sekolah penderita thalasemia sebagian besar termasuk kategori baik, terutama universal selfcare, sedangkan yang masih kurang pada aspek developmental selfcare. Terdapat hubungan yang signifikan antara pengetahuan dan dukungan sosial, namun tidak adanya hubungan yang signifikan antara status kesehatan, jenis kelamin dengan selfcare behavior. Variabel pengetahuan merupakan variabel yang paling berpengaruh dan usia merupakan faktor perancu yang mempengaruhi selfcare behavior anak usia sekolah penderita thalasemia mayor.

Hasil penelitian ini mengungkapkan bahwa halhal yang perlu ditingkatkan oleh perawat maupun tenaga kesehatan lain dalam merawat anak sekolah dengan thalasemia dan keluarganya. Perawat perlu menyusun program pendidikan yang dibutuhkan untuk memandirikan anak usia sekolah. Perawat juga bisa membantu menurunkan angka kejadian thalasemia.

Penelitian lebih lanjut mengenai faktor-faktor yang tidak dapat dibuktikan dalam penelitian ini, misalnya status kesehatan dan faktor keturunan, perlu dilakukan karena secara kepustakaan didapatkan bahwa status kesehatan berhubungan dengan kemampuan selfcare behavior (WK, $\mathrm{NN}, \mathrm{KN}$ ). 


\section{Referensi}

Fan, L. (2008). Self-care behavior of school age children with heart disease. Pediatric Nursing, 34 (2), 131-138.

Hockenberry, M.J., \& Wilson, D. (2009). Wong's esensials of pediatric nursing. Phildelphia: Mosby Elseiver.

Lee, Y.L., Lin, D.T., \& Tsai, S.F. (2008). Disease knowledge and treatment adherence among patients with thalassemia major and their mothers in Taiwan. Journal of Clinical, 18, 529-538.

Lenoci, J.M., Telfair, J., Cecil, H., \& Edward, R.R. (2002). Self-care in adult with sickle cell disease. West J Nurse Res, 24 (3), 228245 .

Martin, M.B., Foote, D., \& Carson, S. (2004). Help your patiens meet the challenges of a thalassemia major. Diperoleh dari www.nursing 2004.com.

Newland, J. (2008). Factor influence independence in adolescents with sickle cell dieses. Journal of Child and Adolescent Psychiatric Nursing, 21 (3), 177-185.
Notoatmodjo, S. (2003). Pendidikan dan perilaku kesehatan. Jakarta: PT Rineka Cipta.

Orem, D. (2001). Nursing concept of practice (6th Ed.). Philadelphia: Lippincott.

Santrock, J. W. (2002). Life span development (8th Ed.). NewYork: McGraw-Hill Companies.

Wahyuni, S. (2008). Thalasemia mayor: Waspadai jika wajah balita terlihat pucat. Diperoleh dari http://www.suarakarya.online.com.

Wong, D.L. (2004). Pedoman klinis: Keperawatan pediatrik (4th Ed.). Jakarta: EGC.

Yang, H.C., Chen, Y.C, Mao, H.C., \& Lin, K.H. (2001). Ilness knowledge, social support and selfcare behavior in adolescent with betathalassemia mayor. Hu Lin Yan Jiu, 9 (2), 114122.

Yayasan Thalassemia Indonesia. (2009). Grafik data penderita Thalassaemia yang berobat di Pusat Thalassaemia RSCM. Diperoleh dari http://thalassaemiayti.or.id/data_penderita. htm. 